\title{
Authentic happiness theory supported by impact of religion on life satisfaction: A longitudinal analysis with data for Germany
}

\section{Bruce Headey , Juergen Schupp , Ingrid Tucci \& Gert G. Wagner}

To cite this article: Bruce Headey, Juergen Schupp , Ingrid Tucci \& Gert G. Wagner (2010) Authentic happiness theory supported by impact of religion on life satisfaction: A longitudinal analysis with data for Germany, The Journal of Positive Psychology, 5:1, 73-82, DOI:

10.1080/17439760903435232

To link to this article: https://doi.org/10.1080/17439760903435232

Published online: 28 Jan 2010.

Submit your article to this journal $\square$

Џ Article views: 1552

Q View related articles $\sqsubset$

4 Citing articles: 41 View citing articles 


\title{
Authentic happiness theory supported by impact of religion on life satisfaction: A longitudinal analysis with data for Germany
}

\author{
Bruce Headey $^{\text {ab* }}$, Juergen Schupp ${ }^{\text {acd }}$, Ingrid Tucci ${ }^{\text {ae }}$ and Gert G. Wagner ${ }^{\text {adfg }}$ \\ ${ }^{a}$ DIW Berlin; ${ }^{b}$ University of Melbourne, Australia; ${ }^{c}$ Free University Berlin; ${ }^{d}$ IZA Bonn; ${ }^{e}$ Centre Maurice Halbwachs - ERIS \\ (Equipe de Recherche sur les Inégalités Sociales), Paris; ${ }^{f}$ Berlin University of Technology; ${ }^{g}$ Max Weber Institute for \\ Advanced Studies, Erfurt, and Max Planck Institute for Human Development, Berlin
}

\begin{abstract}
Using data from the German Socio-Economic Panel Survey, this paper assesses the relationship between life satisfaction and religious practice. It is shown that individuals who become more religious over time record long term gains in life satisfaction, while those who become less religious record long term losses. This result holds net of the effects of personality traits, and also in fixed effects panel models. The paper has significant implications for the current paradigm theory in SWB research, namely set-point theory. This theory holds that the long term SWB of adult individuals is stable, because SWB depends on personality traits and other stable genetic factors. New evidence in this paper about the effects of consciously chosen life goals, including religious ones, on SWB is hard to reconcile with set-point theory. It is more in line with authentic happiness theory.
\end{abstract}

Keywords: SWB; life satisfaction; religion; set-point theory; authentic happiness theory

\section{Introduction}

The dominant, paradigm theory in SWB research (research on subjective well being) is set-point theory. This theory holds that the long term SWB of adult individuals is stable, because it depends on personality traits and other stable genetic factors. It is already clear from the German panel data that about $20 \%$ of the population have recorded large long term changes in SWB (Headey, 2006, 2008a). New evidence about the effects of consciously chosen life goals, including religious ones, on SWB is also hard to reconcile with set-point theory as currently understood. It is more in line with authentic happiness theory (Peterson \& Seligman, 2004). After a brief discussion of set-point and authentic theory of SWB, the paper assesses the relationship between life satisfaction and religious belief and practice. Using data from the German Socio-Economic Panel Survey (SOEP), it shows linkages between long term changes in religious practice and changes in life satisfaction.

\section{Emerging problems in set-point theory}

Set-point theory has or had all the marks of a paradigm theory for the field of SWB (Kuhn, 1962). It developed cumulatively over the last 30 years, originally going under the label of adaptation-level theory (Brickman \& Campbell, 1971), and appeared to provide an integrated account of linkages between genetic traits, including personality traits, life events, and SWB (Brickman, Coates, \& Janoff-Bulman, 1978; Costa \& McCrae, 1980; Headey \& Wearing, 1989; Lykken \& Tellegen, 1996). Arguably, however, the theory is now beginning to show serious deficiencies. Its major claim and prediction is that, despite transitory fluctuations, long term SWB does not change. Life events produce temporary fluctuations, but the theory claims that adults soon revert to the SWB set-points accounted for by their unchanging personality traits, notably their levels of extroversion (E) and neuroticism $(\mathrm{N})$.

In fact, the central proposition that long term SWB does not change had never, until recently, been directly tested. The German Socio-Economic Panel Survey (SOEP), based on annual interviews with a large representative national sample, has now been running for over 20 years and is the first dataset to enable a direct test. The evidence from SOEP is that about 20\% of the West German prime age adult population have recorded large and apparently permanent changes in their levels of SWB. Taking 5-year averages of life satisfaction in order (largely) to eliminate the effects of transitory annual fluctuations, it transpires that $20 \%$ recorded changes of two or more points on a standard 0-10 life satisfaction scale; close to one and a half standard deviations (Fujita \& Diener, 2005;

*Corresponding author. Email: b.headey@unimelb.edu.au 
Headey, 2006, 2008a). These changes were enough to move them, for example, from the 25th to above the 75th percentile of the SWB distribution, or vice-versa. Many more individuals recorded substantial but lesser changes. Altogether, 35\% recorded changes of one standard deviation or more, when their life satisfaction score in 2000-2004 is compared with 1985-1989.

The new evidence from SOEP cannot readily be reconciled with set-point theory as currently understood. The challenge in developing a new or revised theory is to account for the minority who record substantial changes in long term SWB, as well as for the majority who show little or no change. Obviously, in any new theory, stable personality traits, which are the linchpin(s) of set-point theory, will still have an important role to play. But it is important to realize that these traits are usually regarded as accounting for only $40-50 \%$ of the variance in SWB, although estimates differ widely (Huppert, 2005; Lucas, 2008; but see Lykken \& Tellegen, 1996, for a higher estimate). The SOEP data, in fact, reveal that there are substantial minorities of individuals who have personality traits which would seem to predispose them to low levels of long term SWB, but who actually record high levels. For example, among those recording what is usually thought of as the worst possible combination of traits for SWB (below the mean on E and above the mean on N) $27.0 \%$ were in the top two quintiles of life satisfaction in 2000-2004 and 11.7\% were in the top quintile. Clearly, then, other variables besides personality traits must play a significant role in accounting for SWB, and especially in accounting for long term change.

\section{Authentic happiness theory}

An emerging body of theory which is certainly intended to account for and promote long term change in SWB is authentic happiness theory (Lyubomirsky, King, \& Diener, 2005; Peterson \& Seligman, 2004; Seligman, Parks, \& Steen, 2005). Authentic happiness theorists, who are mainly psychologists, are critical of what they regard as the excessive focus of mainstream SWB theory on satisfaction and pleasure. Their theory has strong moral, sometimes Christian, overtones but is nevertheless clearly empirically testable.

They hypothesize that high levels of long term $S W B$ come from a life characterized by meaning and engagement, as well as pleasure (Seligman et al., 2005). Religious beliefs and behaviors are viewed by many authentic happiness theorists as one valid approach to long term SWB (Myers, 2008; Peterson \& Seligman, 2004). More generally, they hypothesize that life will only appear meaningful to the individual, and will only be satisfying in the long term, if his/her goals or priorities in life are pro-social (altruistic) and are perceived to have intrinsic value, rather than being purely self-oriented and materialistic. Effective engagement in pursuit of these goals/priorities is hypothesized to benefit from the development of various character strengths, which include love, hope, curiosity, and zest (Peterson \& Seligman, 2004). Research in the US and Switzerland indicates that these four character strengths are associated with life satisfaction and with measures of meaning and engagement (Peterson, Ruch, Beerman, Park, \& Seligman, 2007).

Authentic happiness theorists (and others) have conducted both observational and intervention studies designed to test their main hypotheses. Here we briefly review evidence about links between SWB and pro-social goals and behaviors, with particular focus on religion. Lyubomirsky, Sheldon, and Schkade (2005) conducted an experiment in which subjects performed random acts of kindness on a daily basis. Their feelings of positive affect immediately improved and the effect lasted several weeks. Fredrickson (2008) conducted a series of studies of subjects with high levels of positive affect, whether observed or experimentally induced, and found that they recorded improved performance in a wide range of tasks. Exercises involving gratitude ('counting your blessings') have been found to prolong feelings of positive affect and lengthen the period before reversion to an SWB baseline or set-point occurs (Emmons \& McCullogh, 2003; Fredrickson \& Joiner, 2002).

In a recent thorough review of links between SWB and religious beliefs and behaviors, Myers (2008) reports that almost all cross-sectional studies have found positive cross-sectional correlations. Generally, the correlations between life satisfaction and religious practice appear to be in the 0.08 to 0.15 range. Further, religious people appear to cope better with stressful life events (Clark \& Lelkes, 2008; Myers, 2008), and achieve this partly by finding greater meaning in the events and in lessons to be learned from them (Lyubomirsky et al., 2005; Niederhoffer \& Pennebaker, 2002). Religious people tend to have a relatively healthy lifestyle (better diet, less smoking and drinking) and partly for that reason they live a few years longer than average (Myers, 2008). They more commonly serve as volunteers than other citizens and volunteering is associated with somewhat higher SWB (Harlow \& Cantor, 1996; Thoits \& Hewitt, 2001). The frequency of religious activities is also an indicator for measuring social capital which is in turn related to happiness and life satisfaction (Helliwell \& Putman, 2004). 


\section{Research plan: Linking authentic happiness theory to set-point theory and long term $S W B$ by analyzing the effects of religious beliefs and activities}

It is clear that the authentic happiness school is assembling an increasingly impressive body of supporting evidence. At this stage, however, the evidence has several limitations in contributing to a theory of long term SWB. First, much of it comes from intervention studies which demonstrate only short term effects on changes in SWB. Second, the links between SWB and pro-social or religious goals and behaviors are quite modest. Third, nearly all of the studies report these links to SWB without controlling for personality traits. Personality variables should clearly be regarded as temporally and causally antecedent to life goals, so in principle they should be controlled. This is certainly essential in the context of contributing to development of a long term theory of SWB.

In a recent paper on life goals/priorities, using the long term German panel data, the first author attempted to deal with some of these issues (Headey, 2008b; see also Diener \& Fujita, 1995). It was shown that individuals who persistently, over a period of years, pursue pro-social goals register long term gains in life satisfaction, whereas those who pursue self-oriented success and material goals register declines in life satisfaction (see also Diener \& Seligman, 2004; Nickerson, Schwarz, Diener, \& Kahneman, 2003). These linkages held, controlling for the personality traits of extroversion and neuroticism. However, as expected, links between life goals and SWB (and changes in SWB) remained modest, although statistically significant at the 0.001 level.

In theorizing about why pro-social goals can enhance SWB, it was suggested that pro-social goals are non-competitive or non-zero sum (my gain does not detract from your gain, and may even increase your gain), so many people can become better off at the same time. By contrast, material and success goals are generally zero sum, meaning that one person's gains come at the expense of someone else's losses. So, on average, the community perceives itself as no better off (Easterlin, 1974, 2005).

In our empirical analysis we follow a similar approach in relation to religious beliefs and behaviors. In general terms, these too can be regarded as non-zero sum. We use the SOEP data to assess whether individuals who, over the years, rate religion as highly important in their lives and who regularly engage in religious activities record long term gains in life satisfaction. Personality traits and other fixed effects are included in our statistical models.

So far as we know, these will be the first analyses to assess the impact of changes in religious practice on changes in life satisfaction. Previous analyses have focused only on the static relationship. If, indeed, we find that the two sets of changes are linked, it will have important implications for SWB theory. Set-point theory, as now understood, cannot readily accommodate results showing that consciously chosen life goals, or consciously chosen religious beliefs and practices, can make a significant difference to SWB. We discuss these broader implications in the concluding section of the paper.

\section{Method}

\section{Sample: SOEP panel data}

The SOEP is the longest-running panel survey in the world to collect data on life satisfaction (Wagner, Frick, \& Schupp, 2007). It began in 1984 in West Germany with a sample of 12,541 respondents. Interviews have been conducted annually ever since. Everyone in the household aged 16 and over is interviewed. The cross-sectional representativeness of the panel is maintained by interviewing 'split-offs' and their new families. So when a young person leaves home ('splits off') to marry and set up a new family, the entire new family becomes part of the panel. The sample was extended to East Germany in 1990 and since then has also been boosted by the addition of new immigrant samples, a special sample of the rich, and recruitment of new respondents partly to increase numbers in 'policy groups'. The main topics covered are family, income, and labor force dynamics, but a question on life satisfaction has been included every year.

This paper is confined to analyzing links between life satisfaction and religious beliefs and practices. One issue was whether to include adherents of all religions or whether to confine analysis to Christians and non-religious people only. All main findings were essentially unchanged whichever approach was adopted, so it was decided to include everybody. In Germany most adherents of religions other than Christianity are immigrants; the largest minority being Muslims. The inclusion of Muslims and other non-Christians introduces cultural differences which we cannot fully control for in the analysis. Note, however, that the variable 'foreign born' is included as a control in analyses.

Balanced panel results reported in this paper (Tables 3 and 4) relate to the approximately 1500 respondents who repeatedly reported their levels of life satisfaction, religious attitudes, and behavior between 1990 and 2005. Analyses using cross-sectional and unbalanced panels are based on much larger samples (Tables 1, 2, and 5). In 2005, the latest year in which 
data on religion were collected, just over 20,000 respondents answered the relevant questions.

\section{Measures}

\section{Life satisfaction}

The dependent (outcome) variable in all equations is life satisfaction, which is measured in SOEP on a $0-10$ ('totally dissatisfied' to 'totally satisfied') scale. This single item measure is plainly not as reliable or valid as multi-item measures of SWB, but it is widely used in international surveys and has been reviewed as acceptably valid (Diener, Suh, Lucas, \& Smith, 1999). In this article we often require longer term measures of life satisfaction (indications of each individual's set point) rather than one-off measures which are subject to temporary fluctuations. So, in line with earlier research, 5-year averages of life satisfaction scores (1990-1994, 1995-1999, and so on) will be used (see also Fujita \& Diener, 2005; Headey, 2006, 2008a, 2008b). It has become more or less conventional, when using a $0-10$ life satisfaction scale, to acknowledge that the scale is strictly speaking only ordinal, but then to proceed to treat it as an interval scale in regression analysis.

\section{Religious beliefs and activities}

Religious attitudes and priorities are measured intermittently rather than annually in SOEP. In 1994, 1998, and 1999, respondents were asked about the importance of religion in their lives. This question was presumably intended to tap into a spiritual dimension, the extent to which religion provides a sense of purpose and meaning to life. A 4-point scale was used, running from 'not at all important' to 'very important'. On 11 occasions between 1990 and 2005, respondents have also been asked a question intended to tap the organizational and social dimension of religion. They are asked about the frequency with which they attend church or engage in other religious activities. Again, a 4-point scale is used, running from 'never' to 'at least once a week'.

As was the case with life satisfaction, we shall want to use longer term measures of the 'importance of religion' and of 'religious activity'. As before, the approach will be to average scores from multiple waves of data.

As expected, the two variables 'importance of religion' and 'religious activity' are highly correlated; over 0.65 . Even so, where feasible, we include both as explanatory variables on the right hand side of equations. The effect is simply to partition the variance accounted for by 'religion' into roughly two equal parts.
The questions about religion are of course put to all SOEP respondents: Christians, adherents of other religions, and non-religious people. Muslims comprise the largest non-Christian religious group. Preliminary analysis indicated that links between life satisfaction and religious belief and practice appeared not to vary between groups, so all are included in this paper.

\section{Personality traits}

In 2005 the SOEP study made its first major investment in measuring personality traits. The chosen instrument was a short version of the Big Five Personality Domains: NEO-AC (Costa \& McCrae, 1991). The traits in the Big Five are extroversion (E), neuroticism $(\mathrm{N})$, openness $(\mathrm{O})$, agreeableness $(\mathrm{A})$, and conscientiousness (C). SOEP used short versions of the five scales which are reported to be satisfactorily correlated with the much longer versions developed by psychologists (Gerlitz \& Schupp, 2005).

For present purposes, the inclusion of personality traits is essential because it is certain that some traits, notably $\mathrm{E}$ and $\mathrm{N}$, are related to life satisfaction and so should be 'controlled' on the right hand side of equations in which the aim is to assess the impact of religious attitudes and behavior on life satisfaction. As noted above, this approach is also necessary in any attempt to integrate the insights of set-point theory with those of the authentic happiness school. It should be stressed that, by including personality traits measured in 2005 on the right hand side of equations to account for life satisfaction in earlier years, we are in effect assuming that personality is stable. If it were completely stable, then of course it would not matter when it was measured. However, the assumption is not completely correct. It is thought that ratings on personality traits can be changed to a moderate degree, especially among younger adults, by life experiences like having a stable marriage or an absorbing job (Roberts, Walton, \& Viechtbauer, 2006; Scollon \& Diener, 2006).

\section{Results}

A preliminary point of information, which is relevant to the linkage between religion and life satisfaction, is that $18-19 \%$ of Germans (about $22 \%$ in West Germany and $8 \%$ in the East) report that they now attend church at least once a month. The fairly low figures suggest that church-going must, in most cases, be a chosen activity, not a matter of social conformity. It is also of interest that in the 16 years for which SOEP provides evidence (1990-2005), there was no decline in church attendance, although some observers believe that that they detect a long term secularization of 
Table 1. Impact of religious belief and behavior on life satisfaction: OLS regressions (metric coefficients with standardized coefficients for Model 2 in parentheses). ${ }^{a}$

\begin{tabular}{|c|c|c|}
\hline Explanatory variables & $\begin{array}{l}\text { Life Sat. } \\
\quad(0-10) \\
\text { Model (1) }\end{array}$ & $\begin{array}{l}\text { Life Sat. } \\
(0-10) \\
\text { Model (2) }\end{array}$ \\
\hline Importance of religion & $0.12 * * *$ & $0.13(0.07) * * *$ \\
\hline Religious activities & $0.11 * * *$ & $0.09(0.05)^{* * *}$ \\
\hline Female & 0.03 & $0.05(0.01)$ \\
\hline Age & $-0.04 * * *$ & $-0.08(-0.70) * * *$ \\
\hline Age squared/10 & $0.01 * * *$ & $0.01(0.68)^{* * *}$ \\
\hline Foreign born $(1-0)$ & $-0.13 * *$ & $-0.07(-0.01)$ \\
\hline Extroversion & $0.14 * * *$ & $0.14(0.10)^{* * *}$ \\
\hline Neuroticism & $-0.29 * * *$ & $-0.27(-0.19) * * *$ \\
\hline Partnered $(1-0)$. & & $0.39(0.11)^{* * *}$ \\
\hline Years of education & & $0.01(0.11)$ \\
\hline $\mathrm{HH}$ disposable income/1000 & & $0.01(0.14)^{* * *}$ \\
\hline Health disability $(1-0)$ & & $-0.60(-0.11)^{* * *}$ \\
\hline Adj. $R$ squared & $7.4 \%$ & $11.5 \%$ \\
\hline$N$ & 6568 & 6203 \\
\hline
\end{tabular}

Source: SOEP, 1999; the latest year in which both variables relating to religion were included in the same survey.

${ }^{\text {a }}$ Standardized coefficients are given for Model 2 solely to clarify issues relating to effect sizes in the Discussion section. $* * *$ significant at $0.01 ; * *$ significant at 0.05 ; *significant at 0.10

German society (Halman \& Pettersson, 2006; see also Beck, 2008). Additional descriptive information relating to religion and other variables is provided in the Appendix.

\section{Cross-sectional results: Support for the literature}

As noted in the introduction, researchers in many countries have found statistically significant but substantively quite modest cross-sectional relationships between life satisfaction and aspects of religious belief and behavior. The SOEP data replicate these results for Germany, both with regard to the importance people attach to religion in their own lives and to frequency of engagement in religious activities, including church attendance. ${ }^{1}$ However, a new contribution in Table 1 comes from assessing whether the linkages still hold, controlling for the personality traits of extroversion and neuroticism, as well as other potentially confounding variables. In model (1) we control only for variables which should plainly be regarded as causally antecedent to or coterminous with the religion variables: gender, age, and country of birth, plus personality traits. In model (2) controls are also in place for marital/partner status, education, income and health. The causal logic here is debatable, since it might plausibly be argued that these variables could be influenced by religious beliefs and behaviors.
The bivariate correlation between life satisfaction and 'importance of religion' is only 0.09 and the correlation with 'religious activities' is 0.10 . Despite these lowish correlations, the results in Table 1 show that the relationships remain significant at the 0.01 level in both regression models. In fact, in the multivariate analysis, the two religious variables combined appear to be about as strongly (or weakly) related to life satisfaction as extroversion, which SWB researchers generally regard as a key explanatory variable.

Further analysis showed that the link between religion and life satisfaction was not reduced when extra 'controls' were added, beyond the standard lists in Table 1. These extra controls related to employment status, physical and mental health, and total availability of leisure time. In Germany, as elsewhere in Europe, more women than men profess religious belief and attend church. A plausible hypothesis, perhaps, is that religion is more closely associated with life satisfaction for women than men. Table 2 reports similar results to Table 1 but with a gender breakdown.

The ad hoc hypothesis that religion would have greater impact on the life satisfaction of women than men receives no support. There were no statistically significant gender differences at all in the coefficients linking the importance of religion or religious activity to satisfaction. It should also be recorded that there were no East-West German differences in the strength of the link between religion and life satisfaction, although church-going is over twice as prevalent in the West. As noted earlier, results were also unaffected by inclusion or exclusion of the fairly small number of SOEP respondents, mostly immigrants, espousing religions other than Christianity. In the case of Muslims (the largest of the 'minority' groups) the links between religion and life satisfaction appeared to be about the same as among Christians.

\section{Longitudinal results: Long term changes in religious activity are associated with long term changes in life satisfaction}

A major advantage of the panel data is that we are able to assess whether long term changes in religious practice are associated with long term changes in life satisfaction. A reasonable hypothesis, in line with authentic happiness theory, is that people who become more religious over time may record gains in life satisfaction. Conversely, people who become less religious may show a decline in satisfaction. Further, theory would suggest that gains and losses are more likely (and certainly more likely to last) if changes in religious belief and practice are maintained for a lengthy period, rather than being transient. 
Table 2. Impact of religious belief and behavior on life satisfaction: Comparing men and women OLS regressions (metric coefficients).

\begin{tabular}{|c|c|c|c|c|}
\hline Explanatory variables & $\begin{array}{l}\text { Life Sat. } \\
(0-10) \\
\text { Men } \\
\text { Model (1) }\end{array}$ & $\begin{array}{l}\text { Life Sat. } \\
(0-10) \\
\text { Women } \\
\text { Model (1) }\end{array}$ & $\begin{array}{l}\text { Life Sat. } \\
(0-10) \\
\text { Men } \\
\text { Model (2) }\end{array}$ & $\begin{array}{l}\text { Life Sat. } \\
(0-10) \\
\text { Women } \\
\text { Model (2) }\end{array}$ \\
\hline Importance of religion & $0.10 * *$ & $0.14 * * *$ & $0.10 * *$ & $0.15 * * *$ \\
\hline Religious activities & $0.11 * * *$ & $0.10 * * *$ & $0.10 * *$ & $0.07 * *$ \\
\hline Age & $-0.05^{* * *}$ & $-0.04 * * *$ & $-0.09 * * *$ & $-0.07 * * *$ \\
\hline Age squared/10 & $0.01 * * *$ & $0.00 * * *$ & $0.01 * * *$ & $-0.01 * * *$ \\
\hline Foreign born $(1-0)$ & $-0.23 * * *$ & -0.03 & $0.15^{*}$ & 0.01 \\
\hline Extroversion & $0.10 * * *$ & $0.17 * * *$ & $0.10 * * *$ & $0.17 * * *$ \\
\hline Neuroticism & $-0.30 * * *$ & $-0.29 * * *$ & $-0.28 * * *$ & $-0.27 * * *$ \\
\hline Partnered $(1-0)$ & & & $0.48 * * *$ & $0.28 * * *$ \\
\hline Years of education & & & 0.01 & 0.00 \\
\hline $\mathrm{HH}$ disposable income $/ 1000$ & & & $0.01 * * *$ & $0.02 * * *$ \\
\hline Health disability $(1-0)$ & & & $-0.51 * * *$ & $-0.70 * * *$ \\
\hline Adj. $R$ squared & $7.7 \%$ & $7.4 \%$ & $11.7 \%$ & $11.4 \%$ \\
\hline$N$ & 3098 & 3470 & 2925 & 3278 \\
\hline
\end{tabular}

Source: SOEP, 1999; the latest year in which both variables relating to religion were included in the same survey.

$* * *$ significant at $0.01 ; * *$ significant at $0.05 ; *$ significant at 0.10 .

Evidence of long term change is only available for the variable measuring frequency of religious activities; data were collected on 11 occasions from 1990-2005. To assess whether long term change has occurred, we average both life satisfaction scores and scores for the frequency of religious activity scale during the first 5-year period, 1990-1994, and then again for the last 5 years, 2001-2005. Our measures of change for both variables are simply the first difference scores obtained by subtracting Life Satisfaction 1990-1994 from Life Satisfaction 2001-2005, and Religious Activity 1990-1994 from Religious Activity 2001-2005.

We then regress change in life satisfaction on change in religious activity. The same variables are used as 'controls' as in Tables 1 and 2. Additionally, Life Satisfaction 1990-1994 is also included on the right hand side of equations because it is highly negatively correlated with the dependent variable. ${ }^{2}$

Table 3 gives a new and quite important result. It is clear that increases and decreases in religious activity are associated with long term gains and losses in life satisfaction. The effect size is not large but the relationship is significant at the 0.01 level, controlling for a range of possible confounding factors.

In view of the claim in set-point theory that the SWB of mature age people is normally stable, it is important to check whether the result just given holds for this population group. Mature age people, for these purposes, can be defined as those aged between 30 and 69 throughout the period. This excludes not just young people, including young adults, but also seniors whose life satisfaction and levels of religious activity might be
Table 3. Impact of long term change in religious activity on long term change in life satisfaction: OLS regressions (metric coefficients).

\begin{tabular}{lcc}
\hline & Change in Life & Change in Life \\
& Sat. between & Sat. between \\
& $1990-1994$ \& & $1990-1994$ \& \\
& $2001-2005$ & $2001-2005$ \\
& Model (1) & Model (2) \\
Explanatory variables & $\mathbf{0 . 1 4 * * *}$ & $\mathbf{0 . 1 7 * * *}$ \\
\hline Change in frequency of & & \\
$\quad$ religious activities from & & \\
$\quad$ 1990-1994 to & & $0.16^{*}$ \\
$\quad$ 2001-2005 & $0.11^{*}$ & -0.00 \\
Female & -0.00 & 0.00 \\
Age & 0.00 & -0.04 \\
Age squared/10 & -0.11 & $0.13^{* * *}$ \\
Foreign born (1-0) & $0.11^{* * *}$ & $-0.23^{* * *}$ \\
Extroversion & $-0.22^{* * *}$ & $-0.48^{* * *}$ \\
Neuroticism & $-0.45^{* * *}$ & 0.02 \\
Life satisfaction 1990-94 & & $0.03^{*}$ \\
Partnered (1-0) & & $0.01^{* * *}$ \\
Years of education & & -0.07 \\
HH disposable & & $23.1 \%$ \\
$\quad$ income/1000 & & 1525 \\
Health disability (1-0) & & \\
Adj. R squared & $20.1 \%$ & \\
$N$ & 1816 & \\
\hline So & &
\end{tabular}

Source: SOEP, 1990-2005.

$* * *$ significant at $0.01 ; * *$ significant at 0.05 ; *significant at 0.10 .

changed by declining health, or perhaps approaching death.

In the event, it transpires that the impact of changes in frequency of religious activity on life satisfaction is no weaker (if anything marginally stronger) among 
mature age adults than in the population as a whole. It appears that the set-points of prime age individuals can be changed by religion.

\section{Controlling for unobserved fixed effects: Could the link between religious practice and life satisfaction be due to unmeasured variables?}

It remains a possibility that the apparent linkage between religious practice and life satisfaction is wholly or partly due to unmeasured variables, or what economists usually term 'unobserved heterogeneity'. Researchers routinely note this possibility and some speculate on which unmeasured variables may be implicated. For example, Clark and Lelkes (2008) suggest that religious people may be happier than average because they mostly come from religious homes, which may have offered them more stability and emotional security in childhood than is found in the average home. Generally speaking, however, researchers cannot address these issues, precisely because of non-measurement. However, when long-run panel data are available, it is possible to estimate fixed effects models which control for the effects of any omitted confounding variables which, from a within-person standpoint, are fixed or unchanging in their effects. For example, the stability of one's childhood home background (the variable which Clark and Lelkes suggest may be important) is a fixed effect (or constant) within persons, although it is of course variable between persons.

The availability of 11 waves of SOEP data on religious activities and life satisfaction makes it feasible to estimate generalized least squares (GLS) fixed effects models of the relationship between the two variables. The first step is to see if there is any evidence that fixed effects may account for a significant percentage of over-time variance in life satisfaction, when life satisfaction is regressed on religious activity, plus standard control variables (as in Tables 1-4 above). A standard diagnostic test for the presence of variance due to fixed effects is the Breusch-Pagan (1979) test.

In the event, the diagnosis indicated that substantial and statistically significant variance appeared to be due to fixed effects. So we then estimated two fixed effects (within-person) models of year-on-year changes in life satisfaction (Table 5). In the first model the only explanatory variable was frequency of religious activity. Other variables included in previous equations, like gender, age, and personality traits, could not be included precisely because, from a within-person perspective, they are fixed. In the second model, variables on which individuals do record change over time were
Table 4. Mature age adults (30-69): Impact of long term change in religious activity on long term change in life satisfaction: OLS regressions (metric coefficients).

\begin{tabular}{|c|c|c|}
\hline Explanatory variables & $\begin{array}{l}\text { Change in Life } \\
\text { Sat. between } \\
\text { 1990-1994 \& } \\
\text { 2001-2005 } \\
\text { Model (1) }\end{array}$ & $\begin{array}{c}\text { Change in Life } \\
\text { Sat. between } \\
\text { 1990-1994 \& } \\
\text { 2001-2005 } \\
\text { Model (2) }\end{array}$ \\
\hline $\begin{array}{l}\text { Change in frequency } \\
\text { of religious activities } \\
\text { from } 1990-1994 \\
\text { to } 2001-2005\end{array}$ & $0.20 * * *$ & $0.19 * * *$ \\
\hline Female & 0.09 & 0.07 \\
\hline Age & 0.04 & -0.00 \\
\hline Age squared/10 & -0.00 & 0.00 \\
\hline Foreign born $(1-0)$ & $-0.22^{* *}$ & -0.10 \\
\hline Extroversion & $0.11^{* * *}$ & $0.12 * * *$ \\
\hline Neuroticism & $-0.19^{* * *}$ & $-0.19 * * *$ \\
\hline Life satisfaction $1990-1994$ & $-0.42 * * *$ & $-0.43 * * *$ \\
\hline Partnered $(1-0)$ & & -0.17 \\
\hline Years of education & & $0.04 * *$ \\
\hline $\begin{array}{l}\mathrm{HH} \text { disposable } \\
\text { income } / 1000\end{array}$ & & $0.01 * *$ \\
\hline Health disability $(1-0)$ & & -0.04 \\
\hline Adj. $R$ squared & $18.2 \%$ & $20.2 \%$ \\
\hline$N$ & 946 & 877 \\
\hline
\end{tabular}

Source: SOEP, 1990-2005.

***significant at 0.01 ; **significant at 0.05 ; *significant at 0.10 .

included: marital/partner status, years of education, disposable income, and disability status.

The main difference between the analyses reported in Table 5, compared with Tables 3 and 4, needs to be reiterated. The previous tables dealt with the important issue for SWB theory of the linkage between long term changes in religious activity and long term changes in life satisfaction. Table 5 really just addresses a methodological issue about unmeasured variables/unobserved heterogeneity, and uses only short term (year-on-year) data about change. The results from these final analyses show that the link between religious activity and life satisfaction holds up, and remains significant at the 0.01 level, when account is taken of unmeasured fixed effects. The effect sizes (Bs) for the religious activity variable are weaker than in the previous analysis, which dealt with long term change, but this is exactly what one would expect, given annual data and controls for fixed effects.

\section{Discussion}

\section{Implications for SWB theory}

Evidence from the long running German Socio-Economic Panel has increasingly important implications for SWB theory. This paper has shown 
Table 5. Fixed effects models of the link between year-onyear changes in religious activity and life satisfaction: GLS regressions (metric coefficients).

\begin{tabular}{|c|c|c|}
\hline Explanatory variables & $\begin{array}{l}\text { Annual changes } \\
\text { in Life Sat. } \\
\text { 1990-2005 } \\
\text { Model (1) }\end{array}$ & $\begin{array}{l}\text { Annual changes } \\
\text { in Life Sat. } \\
\text { 1990-2005 } \\
\text { Model (2) }\end{array}$ \\
\hline $\begin{array}{l}\text { Annual changes in } \\
\text { frequency of religious } \\
\text { activities from } \\
1990 \text { to } 2005\end{array}$ & $0.08 * * *$ & $0.05 * * *$ \\
\hline Partnered (1-0) & & $0.18 * * *$ \\
\hline Years of education & & -0.01 \\
\hline $\begin{array}{l}\mathrm{HH} \text { disposable } \\
\text { income } / 1000\end{array}$ & & $0.01 * * *$ \\
\hline Health disability $(1-0)$ & & $-0.15 * * *$ \\
\hline Adj. $R$ squared & $1.3 \%$ & $3.7 \%$ \\
\hline$N$ & 131485 & 73072 \\
\hline
\end{tabular}

Source: SOEP, 1990-2005. Life satisfaction was measured in all years. Religious activity was measured in all years except 1991, 1993, 2000, 2002, and 2004. The Ns relate to all years of data combined.

***significant at $0.01 ; * *$ significant at 0.05 ; significant $^{2}$ at 0.10 .

that religious beliefs and activities make a significant long term difference to life satisfaction. This result is very much in line with authentic happiness theory and sits uneasily with set-point theory, which is currently the dominant theory in the field. Previous analyses based on the German panel have already cast doubt on set-point theory by showing that the SWB of at least $20 \%$ of adults appears to have undergone long term change during the last 20 years (Headey, 2006, 2008a). Also, and in line with authentic happiness theory, it has been shown that differences in life goals have substantial effects on life satisfaction (Headey, 2008b). Individuals who persistently pursue altruistic, non zero sum goals record lasting gains in satisfaction, just as do people who increase their involvement in religious activities. This is in contrast to contrast to life events, like gaining a promotion or the birth of a child, which generally have only short term effects on satisfaction (Headey, 2008a, 2008b; Lyubomirsky, 2007; Peterson \& Seligman, 2004). In this context Lyubomirsky (2007) has speculated that it may eventually be found that genes account for about $50 \%$ of the variance in life satisfaction, life events $10 \%$, and intentional activity about $40 \%$.

Aside from such speculations, it is reasonable to ask how big a difference religious belief and behavior make to life satisfaction. Are the effects substantial or merely statistically significant? When questions of this kind are raised about regression results dealing with attitudes, they are often difficult to answer because effect sizes may have no clearly meaningful interpretation, based as they are on arbitrary scales (e.g. the $0-10$ life satisfaction scale). One approach is to compare standardized coefficients (Betas); coefficients for variables transformed to have a mean of zero and a standard deviation of 1.0. If we take the evidence for Model (2) in Table 1, we find that the combined effects of religious belief $($ Beta $=0.07)$ and religious activity $($ Beta $=0.05)$ on life satisfaction are estimated at 0.12 . This compares with standardized coefficients for extroversion of 0.10 and for neuroticism of -0.19 . As noted earlier, extroversion and neuroticism are considered in set-point theory to be the two key personality traits which keep adult life satisfaction stable.

A second approach to assessing effect sizes is to compare results for religion with results for dummy variables generally regarded as having a strong effect on life satisfaction. It transpires that the moving from ratings of 1 to 4 on both the two religion scales (from religion is 'not at all important' to 'religion is very important to me', and from attending religious activities 'never' to 'at least once a week') is estimated to have approximately the same effect on life satisfaction as getting married $(3 * 0.12=0.36$ versus 0.39$)$. However, while the effect of getting married on satisfaction is generally short term (Clark, Diener, Georgellis, \& Lucas, 2008), the evidence in Tables 3 and 4 suggests that religion has long term benefits. A third approach is to monetarize benefits. The evidence in Table 1 can be interpreted as indicating that an increase in household disposable income of DM 120,000 (about Euros 60,000) would be needed to bring about the same gain in life satisfaction as moving from 1 to 4 on the two religion scales.

It should be conceded that the German data are not ideal for disentangling the relative importance of different dimensions of religion for life satisfaction. Our empirical analyses have mainly concentrated on the effects of changes in religious activity on life satisfaction, but this was solely because the religious activity measure has been collected frequently, whereas other measures are only available for a few years. So we are unable to assess whether changes in religious belief and spirituality, or changes in organizational and religious activity have greater effects on life satisfaction. This is an important issue for future research.

Set-point theory and authentic happiness theory are not directly contradictory, but they point in very different directions. Set-point theory implies that happiness is mainly in the genes. A clear implication is that neither individuals, nor public policy, nor therapeutic interventions can do much to improve matters. Authentic happiness theory, on the other hand, claims that consciously chosen individual goals and behaviors can affect long term SWB. Is it possible to develop a revised account which integrates insights 
from the two theories? Clearly this is likely to prove a difficult assignment, but a preliminary observation may be made. It is fairly clear that the effects of stable traits, of all genetic influences on SWB, are likely to prove larger than the effects of life goals and priorities, including religion. So any new or revised theory will need to be based on accepting that genetic endowments should be seen as basic building blocks, or mulipliers, in any SWB production function.

\section{Acknowledgements}

We wish to thank Christa Fricke, Gerhard Hoehne, and Sybille Meyer for ideas and valuable comments. We are grateful to Philipp Wagner who provided analyses of data from a special SOEP-Study in 2008.

\section{Notes}

1. This result is strongly supported by new results reported by Trautmueller (2008) who finds, based on SOEP data too, that religious people (believers and/or attenders of church services) have larger networks of friends and see their friends more frequently than non-religious people. It is also of interest that a special cross-sectional study of SOEP, which was in the field in August 2008, shows that highly religious respondents report much higher ratings on dimensions like 'empathy','forgiveness', 'reconciliation', 'fairness', and 'teamwork' than respondents with average or low religiosity.

2. SWB researchers are well aware of the large negative correlation found in all panel surveys between life satisfaction at baseline and change in life satisfaction a year later. Including the baseline measure greatly improves the fit of equations.

\section{References}

Beck, U. (2008). Der eigene Gott. Von der Friedensfähigkeit und dem Gewaltpotential der Religionen. Frankfurt am Main- Leipzig: Verlag der Weltreligionen.

Breusch, T., \& Pagan, A. (1979). A simple test for heteroscedasticity and random coefficient variation. Econometrica, 47, 1287-1294.

Brickman, P.D., \& Campbell, D.T. (1971). Hedonic relativism and planning the good society. In M.H. Appley (Ed.), Adaptation level theory (pp. 287-302). New York: Academic Press.

Brickman, P.D., Coates, D., \& Janoff-Bulmann, R. (1978). Lottery winners and accident victims: Is happiness relative? Journal of Personality and Social Psychology, 36, 917-927.

Clark, A.E., Diener, E., Georgellis, Y., \& Lucas, R.E. (2008). Lags and leads in life satisfaction: A test of the baseline hypothesis. Economic Journal, 118, 222-243.

Clark, A.E., \& Lelkes, O. (2008). Deliver us from evil: Religion as insurance. P.S.E., Ecole Normale Superieure, mimeo.
Costa, P.T., \& McCrae, R.R. (1980). Influences of extroversion and neuroticism on subjective well-being. Journal of Personality and Social Psychology, 38, 668-678.

Costa, P.T., \& McCrae, R.R. (1991). NEO PI-R. Odessa, FL: PAR.

Diener, E., \& Fujita, F. (1995). Resources, personal strivings and subjective well-being: A nomothetic and ideographic approach. Journal of Personality and Social Psychology, 68, 926-935.

Diener, E., \& Seligmen, M.E.P. (2004). Beyond Money: Towards and economy of Well-Being. Psychological Science and Public Interest, 5, 1-31.

Diener, E., Suh, E.M., Lucas, R.E., \& Smith, H.L. (1999). Subjective well-being: Three decades of progress. Psychological Bulletin, 25, 276-302.

Easterlin, R.A. (1974). Does economic growth improve the human lot? Some empirical evidence. In P.A. David \& M.W. Reder (Eds.), Nations and households in economic growth (pp. 89-125). New York: Academic Press.

Easterlin, R.A. (2005). Building a better theory of well-being. In L. Bruni \& P. Porta (Eds.), Economics and happiness: Framing the analysis. Oxford: Oxford University Press.

Emmons, R.A., \& McCullough, M.E. (2003). Counting blessings versus burdens: An experimental investigation of gratitude and subjective well-being in daily life. Journal of Personality and Social Psychology, 84, 377-389.

Fredrickson, B.L. (2008). Promoting positive affect. In M. Eid \& R.J. Larsen (Eds.), The science of subjective well-being (pp. 449-468). New York: Guilford Press.

Fredrickson, B.L., \& Joiner, B.L. (2002). Positive emotions trigger upward spirals towards emotional well-being. Psychological Science, 13, 172-175.

Fujita, F., \& Diener, E. (2005). Life satisfaction set-point: Stability and change. Journal of Personality and Social Psychology, 88, 158-164.

Gerlitz, J.-Y., \& Schupp, J. (2005). Zur Erhebung der BigFive-basierten Persoenlichkeitsmerkmale im SOEP. www. diw.de/soep/publikationen

Halman, L., \& Pettersson, T. (2006). A decline of religious values? In P. Ester, M. Braun, \& P. Mohler (Eds.), Globalisation, value change and generations. Leiden: Brill.

Harlow, R.E., \& Cantor, N. (1996). Still participating after all these years: A study of life task participation in later life. Journal of Personality and Social Psychology, 71, 1235-1249.

Headey, B.W. (2006). Subjective well-being: Revisions to dynamic equilibrium theory using national panel data and panel regression methods. Social Indicators Research, 79, 369-403.

Headey, B.W. (2008a). The set-point theory of well-being: Negative results and consequent revisions. Social Indicators Research, 86, 389-403.

Headey, B.W. (2008b). Life goals matter to happiness: A revision of set-point theory. Social Indicators Research, 86, 313-331.

Headey, B.W., \& Wearing, A.J. (1989). Personality, life events and subjective well-being: Towards a dynamic 
equilibrium model. Journal of Personality and Social Psychology, 57, 731-739.

Helliwell, J.F., \& Putnam, R.D. (2004). The social context of well-being. Philosophical Transactions of the Royal Society, 359, 1435-1446.

Huppert, F. (2005). Positive mental health in individuals and populations. In F. Huppert, N. Baylis, \& B. Keverne (Eds.), The Science of Well-Being (pp. 307-340). Oxford: Oxford University Press.

Kuhn, T.S. (1962). The structure of scientific revolutions. Chicago: University of Chicago Press.

Lucas, R.E. (2008). Personality and subjective well-being. In M. Eid \& R.J. Larsen (Eds.), The science of subjective well-being (pp. 171-194). New York: Guilford Press.

Lykken, D., \& Tellegen, A. (1996). Happiness is a stochastic phenomenon. Psychological Science, 7, 186-189.

Lyubomirsky, S. (2007). The how of happiness. New York: Penguin.

Lyubomirsky, S., King, L., \& Diener, E. (2005). The benefits of frequent positive affect: Does happiness lead to success? Psychological Bulletin, 131, 803-855.

Lyubomirsky, S., Sheldon, K.M., \& Schkade, D. (2005). Pursuing happiness: The architecture of sustainable change. Review of General Psychology, 9, 111-131.

Myers, D.G. (2008). Religion and human flourishing. In M. Eid \& R.J. Larsen (Eds.), The science of subjective well-being (pp. 323-346). New York: Guilford Press.

Nickerson, C., Schwarz, N., Diener, E., \& Kahneman, D. (2003). Zeroing in on the dark side of the American dream: A closer look at the negative consequences of the goal for financial success. Psychological Science, 14, 531-536.

Niederhoffer, K.G., \& Pennebaker, J.W. (2002). Sharing one's story: On the benefits of writing or talking about emotional experiences. In C.R. Snyder \& S.J. Lopez (Eds.), Handbook of positive psychology (pp. 573-583). New York: Oxford University Press.

Peterson, C., Ruch, W., Beerman, U., Park, N., \& Seligman, M.E.P. (2007). Strengths of character, orientations to happiness and life satisfaction. The Journal of Positive Psychology, 2, 149-156.

Peterson, C., \& Seligman, M.E.P. (2004). Character strengths and virtues: $A$ handbook and classification. New York: Oxford University Press.

Roberts, B.W., Walton, K., \& Viechtbauer, W. (2006). Patterns of mean-level change in personality traits across the life course: A meta-analysis of longitudinal studies. Psychological Bulletin, 132, 3-27.

Scollon, C.N., \& Diener, E. (2006). Love, work and changes in extraversion and neuroticism over time. Journal of Personality and Social Psychology, 91, 1152-1165.

Seligman, M.E.P., Parks, A.C., \& Steen, T. (2005). A balanced psychology and a full life. In F. Huppert, N. Baylis, \& B. Keverne (Eds.), The science of well-being (pp. 307-340). Oxford: Oxford University Press.

Thoits, P.A., \& Hewitt, L.N. (2001). Volunteer work and well-being. Journal of Health and Social Behavior, 42, 115-131.

Trautmueller, R. (2008). Religion als Ressource sozialen Zusammenhalts - Eine empirische Analyse der religioesen Grundlagen sozialen Kapitals in Deutschland, SOEP paper No. 144: DIW Berlin, Berlin.

Wagner, G.G., Frick, J.R., \& Schupp, J. (2007). Enhancing the power of the German Socio-Economic Panel Study (SOEP) - evolution, scope and enhancements. Schmollers Jahrbuch, 127, 139-169.

\section{Appendix: Sample descriptives ${ }^{\mathrm{a}}$}

\begin{tabular}{lrrc}
\hline & Mean & SD & Corr with LS \\
\hline Life satisfaction (0-10) & 6.95 & 1.83 & - \\
Importance of religion (1-4) & 2.22 & 0.96 & 0.09 \\
Frequency of religious & 1.75 & 0.94 & 0.10 \\
$\quad$ activity (1-4) & & & \\
Protestant (\%) & 33.33 & - & 0.05 \\
Catholic (\%) & 29.97 & - & 0.06 \\
Other Christian (\%) & 2.30 & - & $0.00(\mathrm{~ns})$ \\
Non-Christian (\%) & 3.97 & - & 0.03 \\
Non-religious (\%) & 30.42 & - & -0.10 \\
Female (\%) & 50.21 & - & $0.00(\mathrm{~ns})$ \\
Age & 40.06 & 21.80 & -0.06 \\
Foreign born (\%) & 20.77 & - & -0.04 \\
Extroversion (1-7) & 5.29 & 1.23 & 0.19 \\
Neuroticism (1-7) & 3.96 & 1.22 & 0.28 \\
\hline
\end{tabular}

${ }^{\text {a }}$ Results are for the latest year available in 1990-2005 (usually 2005). Sample sizes vary.

${ }^{\mathrm{b}}$ Pearson product moment correlations with Life Satisfaction. All are significant at the 0.001 level unless marked 'ns'. 'ns' $=$ not significant at the 0.001 level. 